Institute of $\mathbf{F}_{\text {ood and }} \mathbf{A}_{\text {gricultural }} \mathbf{S}_{\text {ciences }}$

\title{
Cow Math - Using Weaning Weight to Estimate Cowherd Productivity 1
}

John Arthington and James Stice ${ }^{2}$

\section{Records and Data Collection}

The ability to measure performance is a key component in all beef cow operations. Regardless of size, producers must be able to identify the current status of their operation in order to make adjustments toward improvement. Cow culling is a key management tool for herd improvement. Being able to identify the poorer producing cows within a herd is essential. The old adage, "You can't get where you're going unless you already know where you are," certainly holds true in beef cattle management.

One of the growing areas of cowherd record management involves the use of commercial software geared specifically for beef cow/calf operations. These can vary tremendously in level of complexity. Although these are very often an affordable option, many small cattle producers have chosen other routes of record keeping. A recent USDA-APHIS survey showed that over $50 \%$ of cattle producers with 300 cows or more used some kind of computer-assisted cow record system compared to less than $15 \%$ of producers with 100 cows or less. In the same study nearly $90 \%$ of these smaller producers indicated that they did use some type of record system. Although small in terms of total cow numbers per producer, these individuals are major contributors to the annual production of beef in the US.

There are multiple methods for determining cow and calf productivity. Some are more complicated than others, however, each require a minimum amount of individual data collection and simple understanding of Cow Math. In this report, we will show how to effectively utilize calf weaning weight records to track the productivity of a cowherd.

Weaning weight is one of the most important, although most abused, measures of cowherd performance. Weaning weight can be calculated in many ways; therefore, it is essential that a producer understand the method of calculation when attempting to estimate his or her production efficiency.

Calf age is an important consideration when calculating weaning weight. Significant variation in weaning age or breeding season can affect the reliability of using weaning weight to measure cowherd productivity. One method of accounting for this variation is adjusting weaning weight to a constant age. A commonly used weaning age

1. This document is AN129, one of a series of the Animal Science Department, Florida Cooperative Extension Service, Institute of Food and Agricultural Sciences, University of Florida. Original publication date December 2, 2002. Visit the EDIS Web Site at http://edis.ifas.ufl.edu.

2. John Arthington, Assistant Professor, Range Cattle Research and Education Center, Ona, Cooperative Extension Service, Institute of Food and Agricultural Sciences, University of Florida, Gainesville, 32611 and James Stice, International Brangus Breeders Association. 
adjustment is 205 days. To adjust, simply calculate calf gain by subtracting the calf's birth weight from its actual weaning weight. Now, divide calf gain by calf age in days. This will be the average daily gain (ADG). Now, multiply ADG by 205 days for a uniform adjustment. To do this, it is important to know the birth date of each calf. This is usually not practical for most commercial producers. The examples used in this report assume a consistent weaning age.

\section{Method 1. Basic weaning weight}

The simplest measure of cowherd performance is calculated by taking the total pounds of calves marketed divided by the number of calves marketed. In this scenario, the basic weaning weight for this herd would be:

(Pounds of calves weaned) $\div$ (number of calves weaned $)=$ basic weaning weight

In this scenario, our basic weaning weight would be:

Herd 1: 8,500 lb of calves weaned $\div 20$ calves $=425 \mathrm{lb}$ per calf

Herd 2: $9,000 \mathrm{lb}$ of calves weaned $\div 18$ calves $=\mathbf{5 0 0} \mathrm{lb}$ per calf

This method has important flaws when attempting to estimate cowherd productivity. Although simple, basic weaning weight does not account for:
A. Differences in calf sex
B. Cow weight
C. Cows that did not calve
D. Calves that died after birth

\section{Method 2. Weaning weight adjusted for calf sex}

Calf weaning weight is influenced by several factors, one of which is sex. Producers who are attempting to compare weaning weights from year to year must consider the differences in steer versus heifer calves present in the annual calf crop. It is simple to correct for these differences.

First we must calculate weaning weight for both steer and heifer calves.

\section{$\underline{\text { Steer Calves }}$}

Herd 1: 4,050 lb of steer calves $\div 9$ steer calves $=450 \mathrm{lb}$ per steer calf

Herd 2: 4,400 lb of steer calves $\div 8$ steer calves $=\mathbf{5 5 0} \mathrm{lb}$ per steer calf

\section{Heifer Calves}

Herd 1: 4,450 lb of heifer calves $\div 11$ heifer calves $=405 \mathrm{lb}$ per heifer calf

Herd 2: 4,600 lb of heifer calves $\div 10$ heifer calves $=460 \mathrm{lb}$ per heifer calf

To adjust for sex we need to calculate the difference in weaning weight between steers and heifers and divide by 2 , therefore:

Herd 1: $450 \mathrm{lb}$ per steer calf $-405 \mathrm{lb}$ per heifer calf $=45 \mathrm{lb} \div 2=23 \mathrm{lb}$

Herd 2: $550 \mathrm{lb}$ per steer calf $-\mathbf{4 6 0} \mathrm{lb}$ per heifer calf $=90 \mathrm{lb} \div 2=45 \mathrm{lb}$

Now we need to adjust weaning weight by subtracting the adjusted difference to steer calves and adding the adjusted difference to heifer calves.

We can multiply the adjusted weaning weight by the total number of steers and heifers and then divide by the total number of calves.

\section{Herd 1:}

Steers: [ $(450 \mathrm{lb}$ per steer calf $* 9$ steers $)-(9$ steers * 23 lb adjustment)]

\section{$+$}

Heifers: [(405 lb per heifer calf $* 11$ heifers $)+$ (11 heifers * $23 \mathrm{lb}$ adjustment)]

$=8,551 \mathrm{lb} \div 20$ calves $=428 \mathrm{lb}$ per calf 


\section{Herd 2:}

Steers: $[(550 \mathrm{lb}$ per steer calf $* 8$ steers $)-(8$ steers $* 45$ lb adjustment)]

$+$

\section{Heifers: [(460 lb per heifer calf $* 10$ heifers $)+$ (10 heifers $* 45 \mathrm{lb}$ adjustment)}

\section{$=9,090 \mathrm{lb} \div 18$ calves $=505 \mathrm{lb}$ per calf}

The sex-adjusted weaning weight differs from the basic weaning weight by $+3 \mathrm{lb}$ in Herd 1 and $+5 \mathrm{lb}$ in Herd 2. This slight increase in adjusted weaning weight is a reflection of the greater number of heifers in this year's calf crop coupled with the tendency for heifer calves to grow at a slower rate compared to their steer contemporaries.

\section{Method 3. Pounds of calf weaned per pound of cow exposed}

Cowherd productivity is affected by many different factors, including but not limited to: 1 ) reproductive efficiency, 2) genetics, 3) nutrition, 4) health, and 5) environmental influences.

Annual costs to maintain a cow can vary greatly. In almost all circumstances, nutritional inputs can absorb 50 to $65 \%$ of total annual costs. Therefore, it is our goal to harvest one calf per cow each year to offset the costs of cow maintenance and ultimately improve profitability. Therefore, by calculating calf weaning weight as a function of the weight of cows exposed to bulls, we are able to best reflect the true production efficiency of the cowherd.

In our scenario, the pounds of calf weaned per pound of cow exposed would be:

$[($ Sex-adjusted weaning weight) $*$ (number of calves weaned)] / (total weight of cows exposed)

\section{Herd 1:}

$[(428 \mathrm{lb}) *(20$ calves $)] /(25,200 \mathrm{lb})=0.34 \mathrm{lb}$ of calf weaned per lb of cow exposed

\section{Herd 2:}

\section{$[(505 \mathrm{lb}) *(18$ calves $)] /(28,800 \mathrm{lb})=0.32 \mathrm{lb}$ of calf weaned per lb of cow exposed}

\section{Which herd is more productive?}

This is often a tough question, which certainly relates to many factors in addition to weaning weight. At the sale barn we often make the generic assumption that the producers marketing the heaviest calves are the most profitable. Sure, they often get the largest check, but what did it cost them to deliver those heavy calves? By taking into consideration the weight of our cows along with the number of calves weaned in relation to cows exposed, we are able to calculate an accurate assessment of the herds productivity. This is an excellent benchmark for comparing cowherd productivity from year to year. This calculation takes into account both cow and calf productivity. Cows will commonly consume 2.5 to $3.0 \%$ of their body weight in dry matter each day. Therefore, larger cows will consume more feed and be more costly to maintain. For example, assuming a dry matter intake of $2.75 \%$, the cows in Herd 2 would consume $100 \mathrm{lb}$ more dry matter per day than the cows in Herd 1. This will total approximately 18 tons of additional feed per year (dry matter basis). This increase in feed costs must be offset by an increase in calf weaning weight and/or an increase in reproductive performance. 
Table 1. Performance summary of two Florida cowherds.

\begin{tabular}{||l|c|c||}
\hline \hline \multicolumn{1}{|c|}{ Measurement } & Herd 1 & Herd 2 \\
\hline No. of cows exposed to bulls & 24 & 24 \\
\hline Total weight of cows exposed, lb & 25,200 & 28,800 \\
\hline Average weight of cows exposed, lb & 1050 & 20 \\
\hline Number of calves born & 22 & 18 \\
\hline Number of calves weaned & 20 & 9,000 \\
\hline Total weight of calves weaned, lb & 8,500 & 500 \\
\hline Average weight of calves weaned, lb & 425 & 8 \\
\hline Total number of steer calves weaned & 9 & 4,400 \\
\hline Total weight of steer calves weaned, lb & 4,050 & 550 \\
\hline Average weight of steer calves weaned, lb & 450 & 10 \\
\hline Total number of heifer calves weaned & 11 & 4,600 \\
\hline Total weight of heifer calves weaned, lb & 4,450 & 460 \\
\hline Average weight of heifer calves weaned, lb & 405 & \\
\hline \hline
\end{tabular}

